\title{
Financial Derivatives: Fiscal Weapons of Mass Destruction
}

\section{Duncan Wigan}

Assistant Professor at the Department of Business and Politics, Copenhagen Business School.

\section{Acknowledgements}

This work is funded by the 'Systems of Tax Evasion and Laundering: Locating Global Wealth Chains in the International Political Economy' (STEAL 2012-15) project funded by the TaxCapDev program under the Research Council of Norway (\#212210/H30).

Contemporary derivatives mark the development of capital and constitute a novel form of ownership. By reconfiguring the temporal, spatial and legal character of ownership derivatives present a substantive challenge to the tax collecting state. While fiscal systems are nationally bounded and inherently static, capital itself is unprecedentedly mobile, fluid and fungible. As such derivatives raise the specter of 'financial weapons of mass destruction'.

\section{Introduction}

Since the eruption of the Global Financial Crisis (GFC) with the collapse of Lehman Brothers in September 2008 two particular policy debates have risen to the top of the agenda. One debate was crystallised in the former head of the UK Financial Services Authority, Adair Turner's comment that the financial sector had, 'swollen beyond its socially useful size... I think some of it is socially useless activity' (Turner 2009: 1). The Turner Review had previously pointed to a financial sector blinded by faith in sophisticated mathematics and the efficient market hypothesis, which had become overblown, over leveraged, over speculative, pro-cyclical and under-regulated (FSA 2009: 11-49). At the same time as politicians were echoing this analysis of the malaise of global finance, an orchestrated attack was launched against the world of 'tax havens'. In April 2009, a G20 communique announced the intention to take action against non-cooperative jurisdictions known parochially as 'tax havens'. The leaders of the G20 nations proclaimed themselves 'ready to deploy sanctions to protect [their] public finances and financial systems', and declared that 'the era of banking secrecy is over' (G20 2009: 4). In the context of widespread austerity policies, both debates have persisted and a host of regulatory initiatives, more or less effective, have been launched. However, while both debates have been intense and persistent, they have remained largely distinct. Despite the G20 statement implicitly linking the problem of adequate public funding to that of the stable provision and allocation of credit, the conversation about the financial system has largely by-passed that about fiscal systems.

International Political Economy has no less failed to forge the link between financial innovation, tax avoidance and the fiscal crisis of the state. The literature on what is now widely known as 'the offshore world' (Palan 2003) has concentrated on the historical development of the international tax architecture, the institutional basis of that architecture in nationally circumscribed mutually exclusive fiscal sovereignty under conditions of economic globalisation, the impact of 'tax havens' on developing countries and multilateral policy efforts to regulate activities in offshore jurisdictions (Burn 1999; Eccleston 2012; Kurdle 2010; Rixen; Palan, Chavagneux and Murphy 2010; Picciotto 1992; Sharman 2006; 2012; Leaman and Warris 2013) This is despite evidence that financial innovation in the form of structured finance ${ }^{2}$ and derivatives is in good part driven by the tax advantages that it can create. Early on, the noble laureate Merton Miller, a leading derivative architect and doyen of the Chicago School, emphasised regulatory and tax 'frictions' in explaining financial innovation (1986). In turn, John Finnerty (1988: 18 ), one of the first to recognize the shift from finance 
as analytical science to finance as engineering science, famously proposed three criteria for financial innovation; innovation must reduce or reallocate risk to lower the required offering yield (cost of credit), lower issuance expenses (cost of financial production), or create a tax arbitrage opportunity (cost of political geography). 'Financial innovations symbolise the profit-driven response to the [sic] changes in the economic, regulatory and tax environment' (Finnerty 1988: 31).

The advantages of combining the political economic analysis of financial innovation and the offshore do not rest purely on the empirical level. Knowledge of the role of derivatives in tax planning remains in large cocooned within a limited sphere of financial practitioners and legal experts, and requires the acquisition of a jargon and expertise endemic to the markets. For most, how derivatives are used to create tax advantages is a black box. Complexity, opacity and secrecy constitute formidable barriers to entry. Nor is the combination entirely policy motivated. In the context of large developed states attempts to repair leaking and emaciated fiscal systems the issue carries urgent and developing policy significance (HMRC 2013; JCT 2011; JCT 2013). In addition to making an empirical and policy contribution, this article is motivated by the need to broaden the analysis of offshore to incorporate spaces which are not sovereign nation states, but rather the product of technical innovations in the private sphere. Errant policy and rogue states are not the only issue here. Financial innovations which rearticulate relations between fiscal and financial systems call for attention and Warren Buffet's famous warning in relation to the then emergent credit derivatives market, that derivatives are potentially 'financial weapons of mass destruction' (2002: 16) might be usefully reposed as derivatives are 'fiscal weapons of mass destruction'. Derivatives corrode both the capacity to collect tax due and the categories and concepts upon which fiscal claims are constructed. A second motivation lies in according derivatives historic significance (Bryan and Rafferty 2006; Wigan 2009: 158). Derivatives mark the evolution of ownership and in doing so reconfigure the materiality of finance. Ownership via abstraction has transcended national containers and garnered unprecedented and diffuse disciplinary power over the state, and in turn labour (cf. Bryan, Martin and Rafferty 2010). A conflict between the fiscal state and financial innovation embodies a deeper structural shift wherein capital has evolved beyond its national imaginary.

In making the argument that derivatives ownership challenges and potentially transcends the fiscal capacity of the state the paper is organized in three subsequent sections. Section one briefly provides some basic facts and figures about financial derivatives to facilitate navigation of the argument then argues for a conceptualisation of derivatives as a new form of ownership. The second section outlines the characteristics of this form of ownership, which lend derivatives their utility in tax avoidance. The section illustrates this by drawing upon two high profile cases where the use of derivatives to minimize tax exposures has come to light. The concluding section discusses the implications of the use of derivatives for tax minimization for understanding financial innovation, financial systems and the evolution of capital. Financial derivatives attract scorn, as instruments of speculation, which destabilize markets and generate crises, and admiration, as the means to market perfection. Understood through the lens of this polemic dichotomy, financial derivatives are either the perverse manifestation of a casino economy or the latest manifestation of a simple evolutionary progress towards complete and perfect markets. This article accords derivatives a historic significance, which transcends the bounds of this debate.

\section{Derivatives and Ownership}

Financial derivatives, which emerged in the immediate wake of the collapse of the Bretton Woods System as a mechanism to harness and navigate the volatility of market driven finance, are contracts the value of which derives from the performance of underlying securities prices, interest rates, foreign exchange rates, commodities and market indexes. Exchange Traded (ET) derivatives are standardised contracts traded on organised exchanges and rest upon the provision of a guarantee by a clearing house. The clearing house stands between the buyer and seller of the contract, collecting margin payments from contract counterparties according to the performance of the underlying asset. At the outset of the GFC counterparty risk - or the risk that you won't get paid - in the over- the-counter (OTC) credit derivative market caused global financial markets to simultaneously seize up on news of the collapse of the U.S. investment bank, Lehman Brothers. In the wake of the GFC a concerted effort has been made to push the derivative trade onto variously designed organized exchanges in order to mitigate the opaque counterparty risk that was so central to the crisis. Despite these efforts the vast majority of the derivatives trade remains OTC. OTC contracts are privately negotiated contracts often tailor made for the buyer. The basic derivative forms are forwards, futures, options and swaps. Forwards are OTC contracts representing an agreement to buy or sell an asset in the future at a given price, the 'strike price'. Futures are exchange traded and represent an agreement to buy or sell an asset at a specified time and price. In both there is a long position and a short position, with long hoping the value of the underlying 
will increase and the short hoping the opposite. Options provide the right to buy ('call') or sell ('put') an underlying asset, but not an obligation to do so. The seller of an option is obliged to sell or buy the asset when the contract matures. Swaps allow two parties to exchange cash flows. For instance, party A may hold a floating interest rate asset and party $\mathrm{B}$ a fixed interest rate asset. If party $\mathrm{A}$ believes interest rates will go down and party $\mathrm{B}$ believes rates will increase there is a rationale for the swap. Notably, while interest rate swaps are the largest part of the swaps market, parties can swap income streams based on virtually any asset. This is ultimately limited only by the contract parties' imaginations.

The derivatives industry is the largest in the world. The notional value of all OTC contracts at end-December 2012 was $\$ 633$ trillion, down from an all-time high of $\$ 706$ trillion at end-June 2011(BIS 2013). It is important to note that the derivatives markets actually grew in the wake of the crisis, suggesting that those who perceived the derivatives trade as a perversion of, or cancerous outgrowth from the 'real economy' of production and trade, and as such a temporary aberration awaiting an inevitable downfall, may need to revisit their commitment to an ideal vision of the economy. Exchange traded derivatives markets are smaller, standing at a notional value of $\$ 67$ trillion at end-June 2013. Notional values reflect the value of the underlying asset referenced. For instance, if a fixed for floating interest rate swap referenced $\$ 1$ billion, its' notional value would be $\$ 1$ billion. However, cash flows exchanged between counterparties will represent the value of changes to the interest rate on $\$ 1$ billion. Accordingly, gross market values record how much it would cost to cancel a contract, or how much money is 'at risk' in a contract, and thus more closely represent the value in the markets at any point in time. At end-December 2012 this figure was $\$ 24.7$ trillion for the OTC markets (Ibid.). To place this in context the combined GDP for all OECD countries in 2011 was $\$ 38.5$ trillion (OECD 2013). Behind these facts and figures regarding derivatives markets lies qualitative historical change.

In commodifying uncertainty as risk, derivatives constitute an evolution in the form of property. Derivatives do not entail direct ownership of an underlying asset, but a synthesized ownership of an exposure to the performance of 'attributes of assets' (Das 2005). This ability to synthesise an asset is key to the utility of derivatives in tax planning. Derivatives permit the construction of a position, which mirrors the economics of a position in some underlying asset or assets, but does not carry the same legal obligations as a position taken directly in those assets. Derivatives disaggregate assets, so that, for instance, ownership of a corporate bond is split between an exposure to the currency of the bond's denomination (currency derivative), exposure to a changing interest rate environment (interest rate derivative) and exposure to the risk that the issuer of the bond will default (credit default swap). One way of thinking this through is to consider derivatives as the manifestation of a third stage in ownership (Bryan and Rafferty 2006: 71-77; Wigan 2009).

The category of property is important in understanding derivatives. Firstly, at base property is a politically defined and invidious mechanism of control. Secondly, in this context, the relationship between derivatives and tax constitutes a confrontation between two forms of property; tax is the property of the state, derivatives the property of the market participant. When risk and property are married in derivatives the object of appropriation lies in a new arena and takes a new form. Under industrial capitalism, property and production were intrinsically entwined. In contrast, derivatives appropriate aspects of circulation and afford the control over those dimensions of assets that are valorised and constituted within circulation. As such the equation of property and derivatives transcends a prior conception of property as direct claims on the material world. Thorstein Veblen's (1924) notion of 'absentee ownership' in the limited liability company, marked the opening up of an historical process wherein ownership progressively abstracts from the physical materials underlying it.

Commonly, ownership is understood to take two forms. First, that of direct private ownership, where the worker is separated from owning the means of production and there is no separation between ownership and management (Kay 1982). Owner-managers have but one means to compete and the liquidation of the owner-manager's relationship to the entity is difficult and expensive. When, for instance, a private company loses a dominant competitive position the owner must sell the entire capital of the enterprise to re-invest in another activity. The flexibility of ownership here is considerably encumbered by a very real physicality. This contrasts with the second stage of ownership. Ownership through equity in the public form of the joint stock company, Veblen's 'absentee ownership' (1924), involves the transfer of ownership on the stock market between numerous and dispersed owners one step removed from the underlying productive process. Through shares, ownership is separated from capital, which in the form of the corporation is given the legal form of a person, persona res. In an evolutionary institutionalist conception of path dependent but open ended historical change (Hodgson 1999) the centre of capitalist competition gravitated from the production process to processes of circulation, or at least processes of circulation begin to define the competitive outcome 
of ownership in tandem with the productive process. The capitalist investor can easily compare the returns on an investment against the returns on all other similar forms of investment and can adjust a portfolio rapidly to beat the average. "[T]here is no place in Big Business for considerations of a more material sort or of a more sentimental sort than net gain within the law. It moves on that plane of make-believe on which the net gain is a more convincing reality than productive work or human livelihood' (Veblen 1924: 217).

Derivatives as a third form of ownership take a distinctly different form. As a second level of abstraction from the underlying capital, derivatives ownership is disconnected from any direct ownership of physical assets, equity or debt ${ }^{3}$. Indeed, this is the very essence of a derivative; ownership takes a form whereby a leveraged exposure to an asset is not predicated on, or limited by, the direct ownership of that asset. It can be synthesized. For instance, a credit derivative, which offers exposure to a firm's performance as debtor - how likely they are to cough up - represents the synthetic ownership of that firm's debt, shorn of other exposures, such as the market interest rate, embodied in a corporate bond. The value of a derivative is determined by movements in the value of the underlying share, bond, currency, or index while bestowing no rights or obligations in regard to the underlying entities. While, the ownership of firms through public equity bridged a division between production and circulation, derivatives render that binary itself problematic in certain terms. The ownership afforded by derivatives rests in circulation unencumbered by direct ties to underlying assets.

Each stage in the evolution of property marks the progressive development of the liquidity and fungibility of ownership (Bryan and Rafferty 2006). In the first stage ownership (and labour) escapes the straitjacket of feudal rights and obligations to be embodied in firms. This is a necessary precondition of liquid ownership and market competition. Ownership must function solely in terms of profit seeking, rather than any alternative value such as kinship or status in feudal hierarchy. In this form ownership is liquid in that firms are compelled to compete or fold. In the form of the joint stock company, equity ownership is separate from control over production. Through shareholding investors obtained a fungible and immanently fleeting form of property. In this context ownership revolves around a share in a company's performance. That performance is gauged against a market average and shares are bought and sold on secondary markets as the owner attempts to 'beat the average'. Ownership now sits between two poles, at one end of which is a particular relation to a company, and the other a more generic relation to accumulation in terms of a claim in the secondary stock market. Here, the owner's legal position bestows upon her no material claim on company property. In the third stage, ownership becomes unencumbered by any linear relationship to specific underlying productive or commercial activity. Derivatives render property eminently fungible. Switching between assets, asset forms and legal jurisdictions is easy and changing the timing of receipts and exposures is integral to the derivative form. As such, derivatives propel the further abstraction of ownership from its 'real economic' basis and lend ownership a truly universal character and novel capacities.

Most importantly in this context, the fungibility and liquidity of ownership via derivatives and the switching and synthesizing functions this affords render derivatives attritional of the fiscal efficacy of the state. Indeed, derivatives effectively transcend legal categories and political geography by integrating them within a contract. When fiscal claims are based on stable categories of asset identity, ownership, jurisdictional competence and timing, derivatives challenge fiscal efficacy. The next section outlines why derivatives might serve these switching and synthesizing functions and in doing so raises the specter of capital transcending the fiscal state.

\section{The Alchemy of Financial Equivalence}

Derivatives challenge fiscal efficacy via the capacity to transform when a fiscal claim is applicable (timing) where that fiscal claim should be applied (source) and to what the fiscal claim is applied (income character or asset identity). These capacities are exercised through the ability of derivatives to permit contract parties to synthetically replicate the economics of a position, without taking on the legal form of that position. Simply, a position on a bond can be synthesized through a position in equity options by entering into put and call contracts. In this example the value of the bond, which will be replicated is 100 . The put and the call are written so that the investor has a right to sell at a given fixed price and buy at a given fixed price at the same time. If the underlying equity moves below 100 the investor can exercise the put at 100 . If the equity moves above 100 , the call written with a strike price of 100 will be exercised and the investor will receive 100 . In effect a position on a fixed income asset (one that returns a predefined sum, such as the bond) has been replicated by a put and a call. The put and call as opposed to providing fixed returns, provide the investor with contingent returns. A position with fixed returns and one with contingent returns may be taxed differently. Consequently, an investor can choose a preferred tax exposure. Further, a swap allows an investor to switch between asset forms and where an asset is located provid- 
ing the investor a choice of where tax is due and on what. Of course tax rates vary across jurisdictions and asset types. Indeed, this legal-geographical differentiation is the grounds upon which the transforming, synthesizing and switching functions of derivatives perform. Further, source, timing and character rules apply differently for equity, debt, options, forwards and swaps but these contracts can be recombined in various ways to produce the returns of any underlying asset. Derivatives 'turbo charge tax shelters' (Sheppard 1999) because they afford the ability to replicate the commercial outcome of a transaction without entering the transaction and incurring the tax exposure associated with such a transaction. This section outlines the challenges posed by derivatives to categories of timing, source, character and identity and explains, on an elementary basis, the mechanics of switching and synthesizing which permit this. The examples given are elementary, but they represent the basic building blocks of derivative based tax arbitrage.

A core fiscal principle is the determination of when an item of income or expense becomes subject to tax. This matters because of the time value of money. A taxpayer is likely to prefer to pay $€ 100$ in two years than pay $€ 100$ tomorrow. In a situation where a tax charge arises on the basis of a triggering event such as an asset sale, it is possible via a derivative structure to replicate the pay off from the asset sale without making the sale. In effect, income can be realized but tax will not be. This is a function of constructing an artificial sale and postponing a real sale, perhaps almost indefinitely. An investor who holds shares the price of which has increased may wish to realize that profit. If the investor sells the shares a capital gains tax will be imposed. On the other hand, an investor could, where legally admissible, buy a put option on the equity from a bank with a strike price of 100 that matures in two years. The current share price is 100 . The investor then sells a call option with the same strike price and maturity. Simultaneously, the investor borrows from the counterparty the full value of all the shares owned using the shares as collateral for the loan. The end effect is stark. The investor realizes gains in the present, but owes no tax now. Further due to the options the investor is no longer exposed to changes in share value. If the share price is higher that 100 when the option matures, the loss on the call offsets this gain. If the share price is lower than 100, the gain on the put option offsets this loss (Martin and Zailer 2001). Eventually the loan will have to repaid, but the contract could be renewed nearing maturity.

The manipulation of source rules follows similar principles. A foreign investor in equities subject to withholding tax on the sale of the equities may turn to an equity swap to alter where the income is sourced for tax purposes. For instance, returns from an investment in U.S. equity by a foreigner will usually be subject to a withholding tax of $30 \%$. However, the investor can receive the same returns through an equity swap in which she receives payments from a counterparty if the value of the equity increases or dividends are paid and makes payments to that counterparty on the basis of interest on the value of equity referenced in the swap and in the event that the value of the equity declines. The source of the income in a swap is based on the residence of the investor, while a direct purchase of equity is sourced where that purchase is made. If that investor is resident, or registered, in an offshore jurisdiction income from the swap may be subject to no tax at all (Levin 2012: 5-6). By artificially replicating a desired equity position a foreign investor can receive the economic benefits of direct ownership without the fiscal obligations attached to it.

Central to fiscal systems and the character of assets for tax purposes is the distinction between income and capital, with income usually taxed at a higher rate than capital gains. Derivatives can transform ownership of an asset from one to the other. Warren (1993) outlines how this can be achieved. As noted, the basis of modern finance theory is that any asset can be replicated with a combination of put and call options on another asset or assets. When assets with fixed returns, like a bond, are taxed as income but those with a contingent return, such as a share, are taxed as capital, an investor is incentivized to replicate the position on a bond via a position in equity combined with put and call options. The investor produces a synthetic zero coupon bond (a bond that pays yield only on maturity), which pays $£ 110$ in 2 years. To replicate this position in assets with contingent returns, returns that will be taxed at the lower income tax rate, the investor buys a share of the same value and two options, enacting what is termed 'put-call parity'. The first option is a put, a right to sell a share at a specified time, 2 years, for a specific price, $£ 110$. The second option is a call, obliging the investor to sell a share at a specified time, 2 years, for a specific price, $£ 110$. If the share price is below $£ 110$ in 2 years the investor will exercise the put and 'put' the shares to the market at $£ 110$. If the share price is above $£ 110$ in 2 years, the holder of the call option will exercise that option and pay the investor $£ 110$. The investor has thus replicated a risk free position in a bond. As such the investor will be taxed on these assets as capital rather than income. A tax inspector would need to combine the three separate contracts to recognize this equivalence.

Hybrid instruments blend features of debt and equity. Different jurisdictions will treat an instrument as debt or equity depending on local rules for doing so. Firms that make cross border investments can take advantage 
of this identity based differential tax treatment. For example, a U.S. firm may make an investment in a subsidiary that issues a hybrid instrument from Luxembourg. That subsidiary will make payments to the U.S. based parent. In Luxembourg, since the hybrid instrument is characterized as debt, the subsidiary will be afforded tax deductions on the interest it pays for the debt and no withholding tax will be levied on those payments as they exit the jurisdiction. However, in the U.S. that payment is not recorded as interest income, but as dividend income, which is subject to less tax (JCT 2011; Johannesen 2012). In the example of a convertible bond, an issuer may sell a bond with an in-built trigger dictating that when the issuer's share price reaches a certain level, the bond is converted into a certain number of shares. This raises the issue of whether the instrument should be characterized as debt or equity for tax purposes. The instrument provides the issuer with deductions on interest paid, while reducing the level of that interest on the basis of the value imputed to the contingent position on the stock. That the same instrument in another jurisdiction may be treated as equity implies that interest that is deductible in the offshore jurisdiction will not lead to taxable interest income in the second jurisdiction where the instrument is treated as equity. This is a case of 'double non-taxation'.

The UK Public Accounts Committee held a hearing in 2012 investigating the marketing of tax avoidance schemes (UK PAC 2013). Evidence was provided by the Directors of three firms specializing in the sale of 'tax mitigation schemes'; Tax Trade, Future Capital Partners and Ingenious Media. These witnesses stated that they relied upon legal opinions of highly ranked barristers, Queen's Counsel (QC), to ratify the legality of schemes they sold. Rex Bretten, then recently retired from the London firm Tax Chambers, was named as one of a handful of QCs who 'prostitute themselves' to schemes devised to create 'tax relief'. Somewhat ironically, Rex Bretten four months subsequently had an appeal against $\mathrm{Her}$ Majesty's Revenue and Customs (HMRC) decision not to allow him to claim tax relief on a $£ 475,000$ loss on an avoidance scheme of his own devising quashed. In February 2003, Bretten with family members had become trustees of two trusts set up by Oakwood Consultants, owned by a firm of accountants. Oakwood exchanged loan notes with a face value for $£ 500,000$ with Bretten in return for $£ 500,000$. The loan notes were constructed to be redeemable for $£ 25,00015$ days after issue, thereby creating the tax-deductible loss. However, the scheme included a call option on the notes held by one of the trustees, which could be redeemed 9 days after issue and before the $15^{\text {th }}$ day of issue for $99.5 \%$ face value. This option was exercised resulting in one of the trusts holding $£ 499,500$ and liability on the loan notes held by the other trust (UK FTT 189: 2013). HMRC deemed the scheme wholly artificial and therefore disallowed the tax-deductible loss on the notes. This case reveals both actors central derivative driven tax avoidance and the simplicity of some of these schemes. Not all are so simple.

In 2013 the CEO of the UK bank Barclays stated in interview, „There are some areas that relied on sophisticated and complex structures, where transactions were carried out primarily to access the tax benefits. Although this was legal, going forward such activity is incompatible with our purpose. We will not engage in it again" (BBC 2013). The Structured Capital Markets division reportedly contributed as much as $£ 1$ bn a year to Barclays' profits by selling complex structured products which had the effect of reducing tax charges or providing artificial deductions - accounting items that can be set against taxes due (Lawrence 2013). Project Knight, one of six such structures revealed by the UK's Guardian newspaper in 2009 and subsequently leaked on wikileaks, involved a proposed 'tax efficient' replication of a loan between Barclays UK and BB\&T U.S. (Guldberg, Hinrichsen and Nielsen 2013). Barclays first set up a UK holding company with approximately $\$ 4 \mathrm{bn}$. The UK holding company then invests this sum in a Luxembourg holding company. The Luxembourg company invests in a further UK limited partnership. The UK limited partnership lends money to BB\&T, but since the UK partnership legally received the money from Luxembourg no tax is due on the profits in either the UK or Luxembourg. Barclays in theory would need to hold capital against the credit risk of the loan, but by writing a credit default swap and a call option on the loan this cost and the risk associated with the loan is avoided. In turn BB\&T set up three subsidiaries in Delaware and one in the UK in which it invested approximately $\$ 1.3 \mathrm{bn}$. This subsidiary invests the money in the UK subsidiary, which has received $\$ 4 \mathrm{bn}$ from the Barclay's subsidiary. After three years the deal is wound up. The structure as presented here is deceptively simple. There are many more steps involved (see Keeley 2007). However, this reduced explanation shows how derivatives can be used in tailoring cross-border products to minimise fiscal exposures. By doing so, and routing the series of transactions through offshore jurisdictions in the U.S and Europe Barclays could provide a loan to BB\&T at below market rate levels and avoid taxation on its profits. Everyone but the taxman is a winner. A comprehensive review of the use of derivatives in tax planning concludes that 'derivatives are appealing because they can replicate financial positions, blur economic substance, and introduce considerable ambiguity in tax reports' and refers to an annual $\$ 100 \mathrm{bn}$ lost to the U.S. Inland Revenue 
Service due to corporate use of derivatives in tax planning (Donohue 2012).

\section{Conclusion}

At first glance, the relationship between derivatives and taxation seems to exemplify the regulatory arbitrage so often associated with financial innovation. These associations are not misplaced and sit well with those who might corral the analysis of derivatives within an idealized and somewhat static vision of capitalism and therefore consider derivatives a cancerous outgrowth from some assumed ideal type political economy. Derivatives have been used to avoid or minimize the impact of regulatory impositions, including those of the fiscal state. However, regulatory arbitrage is a symptom of deeper change driven by derivatives and contemporary financial innovation. Derivatives require us to confront extant concepts of capital and even dismantle nationally framed conceptions. As we have seen, distinct concepts such as equity and capital can be collapsed inside a derivative form. In turn, fiscal architectures are constructed on an imaginary in which capital in all its forms bears a linear relationship to place (source), identity (income character and asset) and time (recognition for tax purposes). Derivatives destabilize these categories through their switching and synthesising functions. What is equity can be capital, what is taxable as income can become subject tax as capital, what is taxed in one jurisdiction can be taxed (differently) in another. This capacity to destabilize both concepts of capital and regulatory architectures built upon such concepts points to the historic import of the derivative form. Capital has transcended the fiscal state and our intellectual means of its appropriation. Desperate attempts to reregulate finance in the wake of the GFC have failed to address this substantial issue and tackling derivatives and tax avoidance continues to rely upon a game of cat and mouse between revenue authorities, the courts and the creators of fiscally attritional financial products.

This article has provided an elementary introduction to why this might be so based on the notion that derivatives are eroding the tax collecting ability of the state. Further research is necessary, but some limitations on that project should be highlighted. First, the precise way in which derivatives are used to 'optimize' tax exposures is subject to a process of constant revision and innovation. The researcher is only aware of mechanisms that have been revealed by leaks or court cases. Secondly, more complex structures are a compound of myriad contracts, which will be reported or accounted for as distinct items. When it is the aggregate effect off a basket of contracts that provides the 'optimal' tax position, this cannot be identified without insider knowledge. In turn, insider knowledge is heavily guarded and access to key players in banks, accountancy firms and law extremely limited. Fourth, the issue requires knowledge in diverse fields; accounting, law, political economy, financial engineering and international and national fiscal and financial regulations all bear on the question. Fifth, tax optimization will rarely rely on one tool. Strategies will combine derivatives with idiosyncratic national rules, opportunities within corporate law and accounting conventions. Interaction across these domains is key. Isolating the effect of one is difficult. This said, the issue does open up a host of avenues to pursue. How does the process of tax driven innovation within banks proceed? Who are the main actors involved and how do they interact? Can national and international fiscal rules intersect efficiently in this context? Is the transcendence argued for here limited to the derivative or might the digital economy and the increasingly intangible nature of capital be generating similar historical outcomes? What concepts of capital, fiscal or otherwise, might be adequate to the derivative form?

\section{Notes}

1. The term 'tax haven' is highly contested and politicised. Almost any state can act as a haven from another's fiscal claim and many states not commonly understood as 'tax havens', such as the UK or Netherlands, design fiscal regimes that attract mobile capital on the basis of tax advantages.

2. Structured finance describes a range of highly complex products sold to companies with bespoke financing requirements. Structured products are built with derivatives and derivative pricing techniques.

3. Commons (1934) distinguishes corporeal or physical assets, incorporeal or paper assets, and intangible or strategic assets. Derivatives might bridge incorporeal and intangible assets or collapse the distinction between the two. This is more likely thinking through the relationship between derivatives and tax.

\section{Bibliography}

BBC 2013, 'Barclays to close 'tax avoidance' unit', BBC News, Business, (available at: http://www.bbc.co.uk/news/business-21397844)

BIS 2013, Quarterly Review, The International Banking Market, Statistical Annex, Bank for International Settlements: Basel, September.

Bryan, Dick and Mike Rafferty 2006, Capitalism with Derivatives: A Political Economy of Financial Derivatives, Capital and Class. Palgrave Macmillan: Basingstoke, New York.

Bryan, Dick, Randy Martin and Mike Rafferty 2009, 'Financialization and Marx: Giving Labor and Capital a Financial Makeover', Review of Radical Political Economics, vol.41, no.4, pp. 458-72.

Buffett, Warren 2003, 'Chairman's Letter' in Berkshire Hathaway Annual Report 2002, Warren E. Buffett.

Burn, Gary 1999, 'The State, the City and the Euromarkets', Review of International Political Economy, vol. 6, no. 2, pp. 225-260.

Commons, John 1934, Institutional Economics: Its Place in Political Economy, Madison: University of Wisconsin Press. 
Das, Sanyajit 2005, Credit Derivatives, CDOs and Structured Credit Products, John Wiley \& Sons: Singapore.

Donohue, Michael 2012, 'Financial Derivatives in Corporate Tax Avoidance: Why, How and Who?' 2012 AAA Annual Meeting - Tax Concurrent Sessions, (available at SSRN: http://ssrn.com/ abstract=2097994).

Eccleston, Richard 2013, The Dynamics of Global Economic Governance: The OECD, The GFC and the Transformation of International Tax Regulation, Edward Elgar: Cheltenham

Finnerty, John 1988, 'Financial Innovation in Corporate Finance: An Overview', Financial Management, vol. 17, no. 4, pp. 14-33.

FSA 2009, The Turner Review: A regulatory response to the global banking crisis, UK Financial Services Authority: London.

G20 2009, Global Plan for Recovery and Reform, Statement Issued by the G20 Leaders, 2 April London, (available at http://www.g20.org/ documents/ (accessed 12.08.13)

Guldberg, Nicholas, Simon Henrichsen and Mark Nielsen 2013, 'Derivatives in Tax Avoidance: The Inadequacy of the Contemporary Taxation System', unpublished Bachelor's dissertation, Copenhagen Business School.

HMRC 2013, 'Modernising the taxation of corporate debt and derivatives,' Consultation document, London: Her Majesty's Revenue \& Customs.

Hodgson, Geoffrey M. 1999, Evolution and Institutions: On Evolutionary Economics and the Evolution of Economics. Cheltenham, UK: Edward Elgar.

Johannesen, Niels 2012, 'Cross-border hybrid instruments' Department of Economics, University of Copenhagen, unpublished manuscript, 16 April. (available at: http://www.nielsjohannesen. net/wp-content/uploads/2012/04/NielsJohannesen_2012_Crossborder-hybrid-instruments.pdf)

Joint Committee on Taxation (JCT) 2011, 'Present Law and Issues Related to the Taxation of Financial Instruments and Products,' Joint Committee on Taxation: Washington.

Joint Committee on Taxation (JCT) 2013, 'Report to the House Committee on Ways and Means on Present Law and Suggestions for Reform Submitted to the Tax Reform Working Groups', Joint Committee on Taxation: Washington.

Kay, Geoffrey 1982, Political Order and the Law of Labour, Basingstoke New York: Palgrave Macmillan.

Keeley, Michael 2007, 'Approvals Paper - Project Knight: BB\&T', Barclays Capital, (available at: http://www.docstoc.com/ docs/68518534/Barclays-Tax-Project-Knight).

Kurdle, Robert 2010, 'Tax Policy in the OECD: Soft Governance Gets Harder', in Kerstin Martens and Anja Jakobi, (eds.) Mechanisms of OECD Governance: International Incentives for National Policy Making, Oxford University Press: Oxford.

Lawrence, Felicity 2013, 'Barclays secret tax avoidance factory that made $£ 1$ bn a year profit disbanded' The Guardian, February 11. (available at: http://www.theguardian.com/business/2013/feb/11/ barclays-investment-banking-tax-avoidance)
Leaman, Jeremy and Warris, Attiya eds. 2013, Tax Justice and the Political Economy of Global Capitalism, 1945 to the Present, Berghahn: New York \& Oxford.

Levin, Carl 2012, 'Closing Ten Offshore Tax Loopholes', Permanent Subcommittee on Investigations, Oct 5, United States Senate: Committee on Homeland Security and Governmental Affairs.

Martin, David and Zailer, Isaac 2001, 'Derivatives Products and Tax Planning', Derivatives Use, Trading \& Regulation, Vol. 7, No. 1, pp. 8-16.

Miller, Merton H. 1986, 'Financial Innovation: The Last Twenty Years and the Next', Journal of Financial and Quantitative Analysis, vol 21, no.4, pp. 459-471.

OECD 2013, 'Gross domestic product (GDP): GDP, US \$, constant prices, constant PPPs, reference year 2005, millions', StatExtract, Organisation for Economic Cooperation and Development, OECD: Paris (available at: http://stats.oecd.org/index.aspx?queryid=556)

Palan, Ronen 2003, The Offshore World: Sovereign Markets, Virtual Places, and Nomad Millionaires, Cornell University Press: Ithaca and London.

Palan, R., Murphy, R., and Chavagneux, C. 2010, Tax Havens: How Globalization Really Works, London: Cornell University Press.

Picciotto, Sol 1992, Internatoinal Business Taxation: A Study in the Internationalization of Business Regulation, Cambridge: Cambridge University Press.

Rixen, Thomas 2008, The Political Economy of International Tax Governance: Transformation of the State, Basingstoke \& New York: Palgrave Macmillan.

Turner, Adair 2009, How to tame global finance, Prospect, 27th August, issue 162, p.1.

Sharman, Jason 2006, Havens in a storm: The struggle for global tax regulation, Ithaca, NY: Cornell University Press.

Sharman, Jason 2012, 'Canaries in the Coal Mine: Tax Havens, the Decline of the West and the Rise of the Rest', New Political Economy, vol.17, no.4, pp. 493-513.

Sheppard, Lee 1999, 'Slow and Steady Progress on Corporate Tax Shelters', Tax Notes,vol. 19, July 9.

UK FTT 189 2013, Bretten v Revenue \& Customs, March 14, (available at: http://www.bailii.org/uk/cases/UKFTT/TC/2013/ TC02604.html)

UK PAC 2013, 'Tax Avoidance: tackling marketed avoidance schemes', Twenty-ninth Report of Session 2012-13, House of Commons Committee of Public Accounts, House of Commons London: The Stationery Office Limited.

Veblen, Thorstein 1924, Absentee Ownership and Business Enterprise in Recent Times. London: George Allen \& Unwin.

Warren, Alvin C., Jr 1993, 'Financial Contract Innovation and Income Tax Policy' Harvard Law Review, Vol. 107, pp. 460-492.

Wigan, Duncan 2009, 'Financialisation and Derivatives: The Political Construction of an Artifice of Indifference' Competition and Change, Vol. 13, No. 2, pp. 159-174. 